\title{
IMPACT OF COVID 19 ON FOOD SECURITY IN INDIA: ASSESSING THE ROLE OF PUBLIC DISTRIBUTION SYSTEM
}

\begin{abstract}
Shilpi Sharma
Sr Research Assistant at "Giri Institute of development studies, Lucknow (India)" it is an Indian council of social science research (ICSSR) supported, one of the premier research institutes in India.
\end{abstract}

DOI: 10.46609/IJSSER.2021.v06i07.012 URL: https://doi.org/10.46609/IJSSER.2021.v06i07.012

\begin{abstract}
This article aims to examine India's food security system and what kind of challenges are being posed with the spread of Covid 19 virus. In this study we will be assessing the role of subsidised public distribution system (PDS) of basic food and non-food commodities in India and further the shift from welfare to right based approach adopted by the Indian government by passing the National Food Security Act (NFSA 2013). For this purpose we will be looking at the decadal population growth and growth of the food grains production of India. We will attempt to understand the relationship between food production and food availability in Indian context. An exploratory methodology has been adopted with comprehensively reviewing the available literature, including government reports, research papers, and reports of international organisations such as United Nations and world bank in the relevant field.
\end{abstract}

Key words: Food security, pandemic, India, Fair Price shops, NFSA 2013

\subsection{Introduction}

With the outbreak of pandemic the entire world came to a halt leaving many deprivedfrom meeting their basic needs. Covid 19 emerged as a health emergency for the world but for the poor and less privileged people it became a challenge for survival. In order to contain the spread of corona virus border controls and lockdown measures were taken by the government which adversely affected supply of essential commodities and livelihoods, and led to an increase in the price of basic food items in most part of the country.

The weakness of our food system got exposed with the COVID-19 pandemic. 'Availability, Access, Stability, and Utilization' of food all four aspects of food security have been severely impacted by Covid 19. 


\section{International Journal of Social Science and Economic Research}

ISSN: $2455-8834$

Volume:06, Issue:07 "July 2021"

The lockdown in India started right around the wheat harvest season in March 2020 and hence did not leave any impact on production rather it impacted procurement, selling and storage of wheat. Due to uncertainties around the official procurement policy during the weeks around the lockdown, to limit the agglomeration of people at mandis(large marketplace) a substantial number of farmers reported adjusting the timing of wheat harvest.It has been reported that almost one third of farmers had to store harvest because there was no market for their produce due to lockdown. This also resulted in lowering their income from harvest and those who were willing to sell their wheat at lower prices they were also not able to do so. The inter-state flow of agricultural goods and equipment also suffered from mandatory border checks and there was no clear information about the exact details of the policies put in place. With the announcement of lockdown, large urban-rural migration of labourers occurred, with people from cities returning to their rural hometowns.

For the people engaged in casual and seasonal low paying jobs such as construction labourers, farm labours, street vendors having little to no financial security all the possible source of earning were unavailable so they became much vulnerable due to Pandemic. In this type of situation maintaining the price of essential commodities is important in order to prevent people from being a marginal earner and meeting bare minimum needs to becoming a poor who is unable to meet basic needs. The food insecure people are disproportionately distributed across different regions of our country they are large in some regions of the country, such as economically backward areas and rural areas and remote ares. According to food and agricultural organisation (FAO) latest statistics (2019) India is the second largest producer of wheat and rice after china, in spite of that limited land for cultivation, climate change, and government policies of public distribution and marketing of food grains and above all pressure of human population have contributed to the slowing down of availability of foods. ${ }^{1}$

\subsection{Population of India and agriculture statistics}

If we look at the demand and supply dynamics of food security then Agricultural output is the supply side of it and population is the demand side. The average percentage growth of population in India is 22.37 percent (calculated from decadal growth given in figure 1). This implies that on an average the population has been growing at 22.37 percent per decade. The population of India is expected to increase from 1.211 billion to 1.518 billion during the period 2011-2036 - an increase of 25 percent in twenty- five years at the rate of 1.0 percent annually. ${ }^{2}$

\footnotetext{
${ }^{1}$ FAO

${ }^{2}$ Ministry of health \& family welfare, Government of India. (2019). "Population projections for India and states $2011-2036$ " report of the technical group on population projections,
} 
International Journal of Social Science and Economic Research

ISSN: 2455-8834

Volume:06, Issue:07 "July 2021"

Figure 1: Decadal Population of India (in Millions)

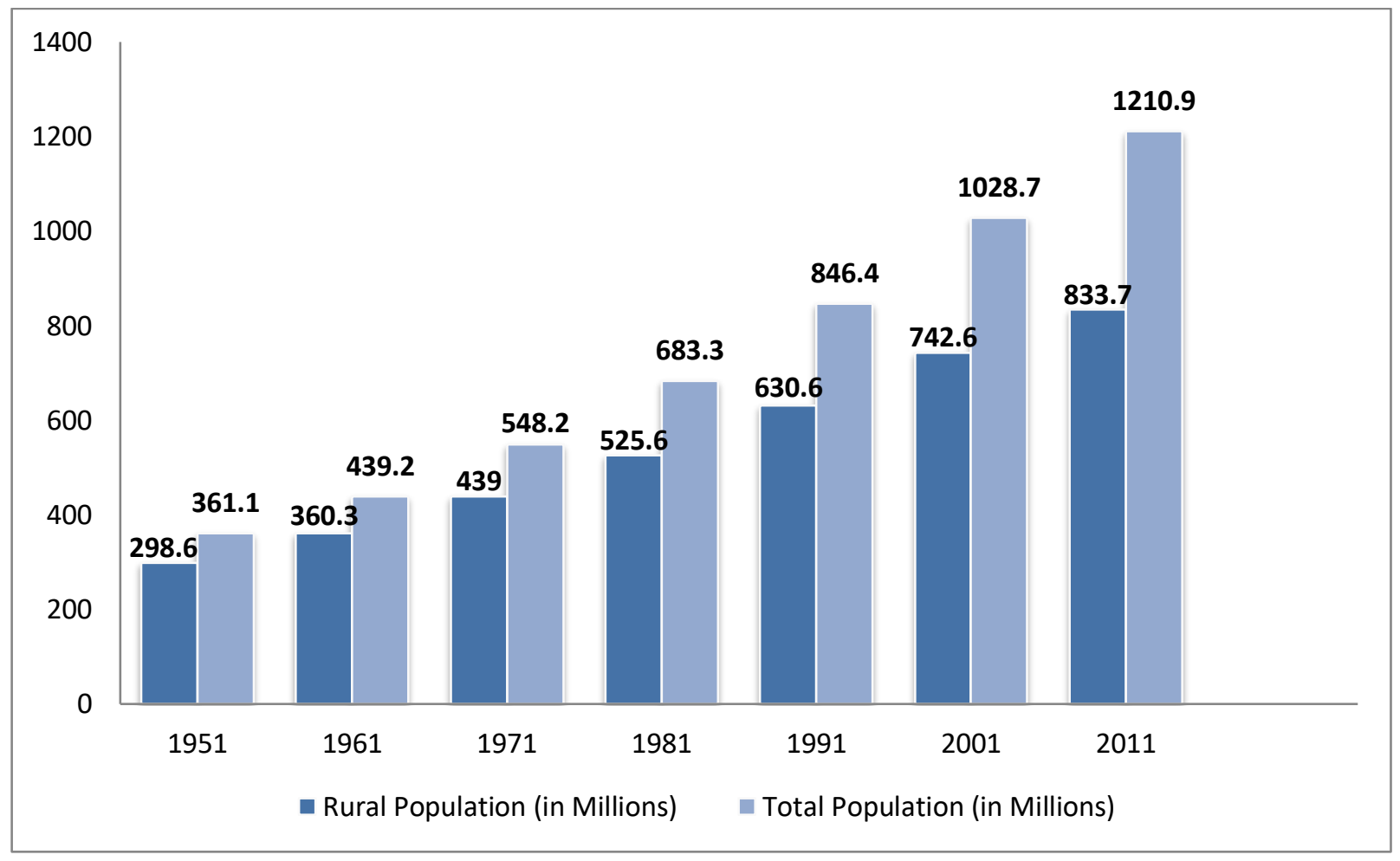

Source: Registrar General of India (censusindia.gov.in)

In a country that has a population of 1.21 billion and which still has the largest number of poor and malnourished people in the world, ensuring food securityby increasing food production and its equitable distribution for the masses should be one of the prime concerns of the government policy.

For the growing population food grains production must grow in order to match the needs. However the growth of food grains production alone is not the answer to the problem of food security. It is affected by various other factors also such as income inequality, poverty, and poor allocation of subsidies. In the year 1951 which is the first census after the independence of India, approximately 82.69 percent of the population was living in rural areas. According to the latest census of India in the year 2011 had approximately 68.84 percent of population living in rural areas (calculated from absolute numbers given in figure 1). This urbanisation of population reflects lesser reliance of people on agriculture for livelihood. Urbanisation also creates demand for agricultural products as raw material to the industries. However over 60 per cent of the Indian population continue to depend on agriculture and allied activities for their livelihood. (World 
International Journal of Social Science and Economic Research

ISSN: 2455-8834

Volume:06, Issue:07 "July 2021"

Bank; 2012). Hence, growth of agriculture sector is essential not just to ensure food for all but for the industrial growth of country.

Figure 2 :Food grains production of India in last decade (in Million Tonnes)

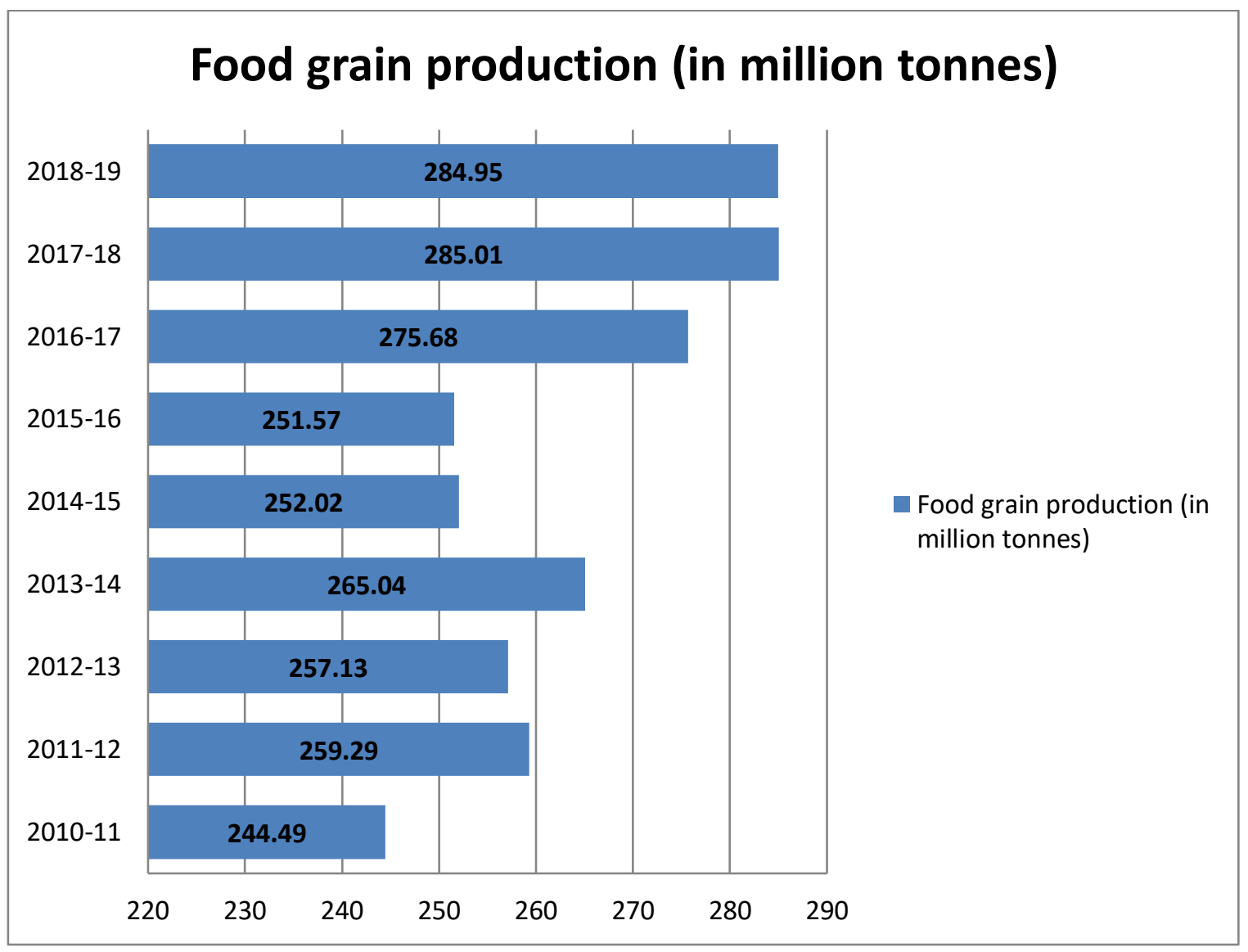

Source: Directorate of Economics and Statistics, DAC\&F (Note: Food grains include- Rice, wheat, maize and nutri cereals)

India has been able to achieve a consistent growth in agricultural output with the year 2019-2020 marking the recordfood production at 291.95 million tonnes. ${ }^{3}$ It is essential to understand that how this produce reaches to end consumers. How much of this is procured or sold in order to reach to the final consumers, what are the arrangements that government makes so that it reaches to the poorest of poor.

\subsection{Overview of India's food policy}

\footnotetext{
${ }^{3}$ Press information bureau government of India ,Pib.gov.in
} 
India's foodpolicy consists of two pillars: (1) government procurement of staple crops from farmers and (2) public distribution of these crops. Food Corporation of India (FCI) is the nodal central agency of Government of India, along with other State Agencies that undertake procurement of wheat and paddy under price support scheme. If the farmers get prices better than the support price from other buyers such as traders / millers etc., the farmers are free to sell their produce to them. The role of Indian government's Department of Food \& Public Distribution is to ensure food security for the country through timely and efficient procurement and distribution of Food grains. This involves procurement of various Food grains, building up and maintenance of food stocks, their storage, movement and delivery to the distributing agencies and monitoring of production, stock and price levels of Food grains. The focus is on incentivizing farmers through fair value of their produce by way of Minimum Support Price mechanism, distribution of Food grains to Below Poverty Line (BPL) families and covering poor households at the risk of hunger. The table 1 shows the procurement of wheat and paddy done in the last decade by government.

The responsibility of achieving food security in India has largely been bestowed on subsidised public distribution of food gains. And the statistics suggest that hardly 10 percent of the food produced is procured by the government.

Table 1: Procurement of Wheat and Paddy for Central Pool (in Million Tonnes)

\begin{tabular}{|l|l|l|}
\hline $\begin{array}{l}\text { Procurement of Wheat and Paddy for Central } \\
\text { Pool (in Million Tonnes) }\end{array}$ \\
\hline Year & Wheat & Paddy \\
\hline $\mathbf{2 0 1 1 - 2 0 1 2}$ & 28.33 & 35.04 \\
\hline $\mathbf{2 0 1 2 - 2 0 1 3}$ & 38.14 & 34.04 \\
\hline $\mathbf{2 0 1 3 - 2 0 1 4}$ & 25.09 & 31.84 \\
\hline $\mathbf{2 0 1 4 - 2 0 1 5}$ & 28.02 & 32.04 \\
\hline $\mathbf{2 0 1 5 - 2 0 1 6}$ & 28.08 & 34.21 \\
\hline $\mathbf{2 0 1 6 - 2 0 1 7}$ & 22.96 & 38.10 \\
\hline $\mathbf{2 0 1 7 - 2 0 1 8}$ & 30.82 & 38.18 \\
\hline $\mathbf{2 0 1 8 - 2 0 1 9}$ & 35.79 & 44.39 \\
\hline $\mathbf{2 0 1 9 - 2 0 2 0}$ & 34.13 & 51.99 \\
\hline $\mathbf{2 0 2 0 - 2 0 2 1}$ & 38.99 & 32.14 \\
\hline
\end{tabular}

Source: department of food and public distribution (report Dec2020) Note: numbers are converted from lakh tonnes to million tonnes.

In addition to PDS, various poverty alleviation programmes are run by the Indian government such as, Integrated Child Development Services (ICDS), Food-for-Work (FFW), Mid-Day Meals andAntyodaya Anna Yojana (AAY). All these programmes are aimed at providing food to poor 
however there has been evident leakage in these schemes. For example earlier the Midday meal to schools and Aanganwadis (mother, child and pre-primary care centres in villages) was provided in the form of uncooked/dry supplies of grains. Later it was discovered that these grains were sold by village heads at a lower rates to locals to be used as cattle feed to increase milk production. ${ }^{4}$ Now to address this problem the government decided to provide cooked meals during lunch time to poor children in these schools.

\subsection{Subsidised Public distribution and its challenges}

In 2013, the Indian Government passed the National Food Security Act (NFSA), which specifies that all Indians have the right to food security this has been conceived as the most substantial step taken by the government towards achieving food for all. The legislation allows eligible households to purchase up to five kilograms of cereals per person, at three rupees per kilogram of rice, two rupees per kilogram of wheat and one rupee per kilogram of coarse grains(one Indian rupee is equal to $\$ 0.20$ ). The Indian Government purchases food grains at a Minimum Support Price (MSP) this is designed to financially support farmers. That purchased grain is then distributed to Fair Price Shops, where ration card holders can buy subsidised food. The NFSA is one of the world's largest social security programmes and 810 million Indians are eligible (D P K Pillay and T k Manoj Kumar; 2019) to purchase the food that it provide there are two types of ration cards under NFSA. ${ }^{5}$

- Priority Household (PHH) ration cards are issued to households that meet the eligibility criteria set by their state government. Each priority household is entitled to 5 kilograms of food grain per member per month.

- Antyodaya Anna Yojana (AAY) ration cards are issued to "poorest of poor" households. Each AAY household is entitled to 35 kilograms of food grain per month.

Table: 2 Ration card holders and beneficiaries

\begin{tabular}{|l|l|l|l|}
\hline \multicolumn{4}{|c|}{ All India ration card holders and beneficiaries } \\
\hline & AAY Ration Cards & PHH Ration cards & Total \\
\hline Ration cards & $23,394,579$ & $212,538,759$ & $\mathbf{2 3 5 , 9 3 3 , 3 3 8}$ \\
\hline Beneficiaries & $110,105,029$ & $682,816,829$ & $\mathbf{7 9 2 , 9 2 1 , 8 5 8}$ \\
\hline
\end{tabular}

Source: National food security portal, Department of food and public distribution, Government of India,https://nfsa.gov.in/public/nfsadashboard/PublicRCDashboard.aspx accessed on 14April 2021 at $14: 33$

4 'Probe misuse of food to anganwadis', February 2011

Read more at: https://www.deccanherald.com/content/138409/probe-misuse-food-anganwadis.html

${ }^{5}$ NFSA government of India https://nfsa.gov.in 
Ration card holders get these food supplies from fair price shops and according to the National food security portal, Department of food and public distribution, Government of India, there are 546,082 fair price shops across India. If we look at the total beneficiaries there are 792.921 million people taking the subsidised food benefit.

\section{Figure 3: Total Fair Price Shops in India}

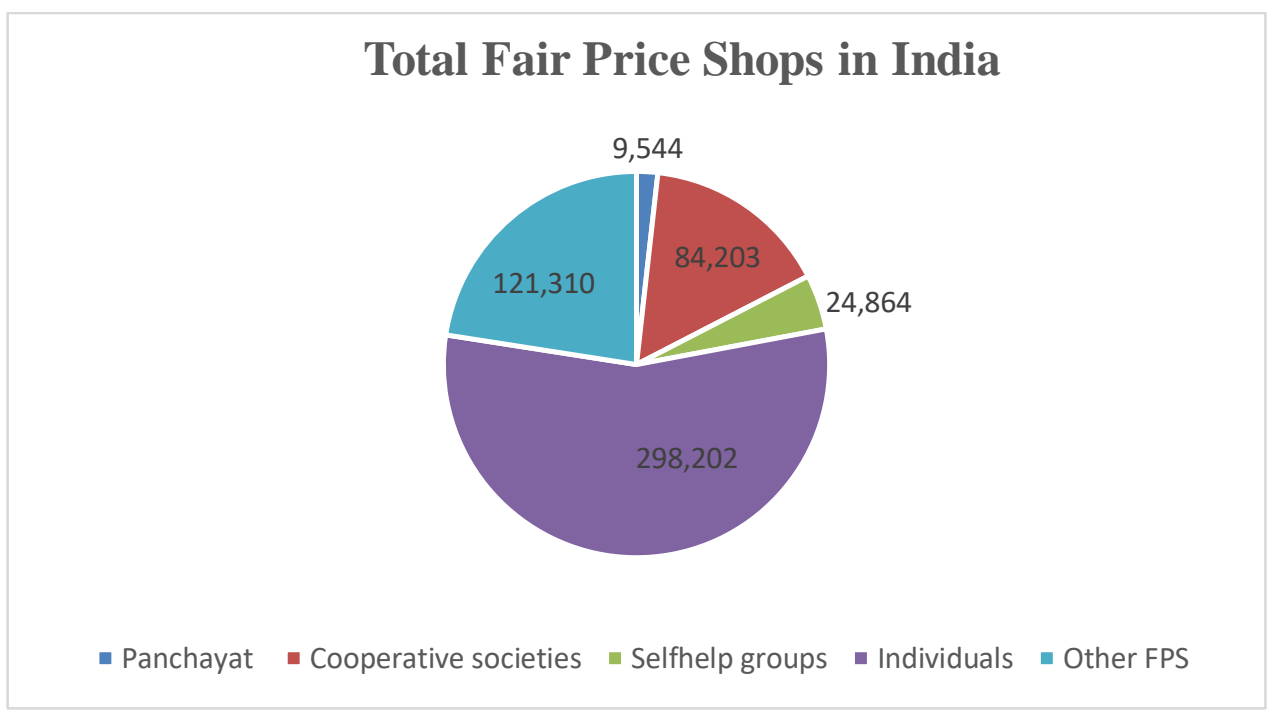

Source: National food security portal, Department of food and public distribution, Government of India,https://nfsa.gov.in/public/nfsadashboard/PublicRCDashboard.aspx accessed on 24 April 2021 at $12: 12$

Out of these 546,082 shops 9,544 are under Panchayat(rural local self-governance),84,203 are under cooperative societies,24,864 are run by self-help groups, and 298,202 run by individuals and rest 121,310 are other FPS. These 546,082 shops have the responsibility of providing ration to $235,933,338$ million ration card holders. The central and state governments share the responsibility of PDS. While the central government is responsible for procurement, storage, transportation, and bulk allocation of food grains, state governments hold the responsibility for distributing the same to the consumers through the established network of fair price shops (FPSs). State governments are also responsible for operational responsibilities including allocation and identification of families, issue of ration cards, and supervision and monitoring the functioning of fair price shops.

The practical inefficiencies of the subsidised PDS (public distribution of food) system came into highlight after the outbreak of COVID-19 pandemic. The economic and social activities came to a halt.Poor people especially the migrant labourers working in factories were severely affected 


\section{International Journal of Social Science and Economic Research}

ISSN: $2455-8834$

Volume:06, Issue:07 "July 2021"

by the sudden announcement of the lockdown in India. Exodus of migrant workers from cities to reach their native places faced a lot of challenges. Many migrant workers walked thousands of miles to reach their villages. One of the reasons of this mass migration was that since these labourers had lost their jobs so they could not afford to feed their families and they could only procure their ration quota of subsidised food from the state they originally belonged to.These workers started fleeing from cities to villages post the announcement of lockdown in March 2020. These migrant workers suffered during covid 19 due to prevalence of a system that did not allow them to get subsidised food from ration shops outside their state their migration was also criticised on the ground that it increased the risk of further spread of the virus. After this incidence Indian government felt the need for implementation of one nation one ration card (ONORC) and hence government announced rolling out the One Nation, One Ration Card scheme in May 2020providing an option to all eligible ration card holders to get their daily quota of food grains from any electronic point of sale (e-PoS) this enables them to access their entitlements from anywhere in the country. This has been named as "one nation one card scheme" by Department of Food \& Public Distribution, Government of India. One nation one card scheme is a small positive step taken by government to provide some relief to poor migrants in need.

\section{Conclusion}

Most Indian farmers possess less than one hectare of land, it implies that most of the farmers are involved in subsistence farming. Efforts should be made to improve the Subsidised distribution of food (PDS) it should be monitored and targeted properly by using methods such as linking of ration cards to the beneficiaries' mobile numbers. Food procurement should be done by easy procedure so that farmers do not end up selling their produce to middlemen. Digital transactions should also be encouraged. Farmers need to be educated about the innovative farming techniques and storage techniques. Their access to government mandis (market) and open market should me such that they do not remain deprived from the best possible price of their produce. However Digitalisation of food procurement and distribution system must not be seen as the single most solution to the problem of food security.

Food security can only be ensured by making the farmers aware about the opportunities they have and the right choices they must make in growing and selling of their produce. Government need to support a sustainable food systems at the forefront so that the menace of hunger and malnutrition can be eliminated. 
International Journal of Social Science and Economic Research

ISSN: 2455-8834

Volume:06, Issue:07 "July 2021"

\section{References}

BaylisKathy et al. (2013). "Impact of Wheat and Rice Export Ban on Indian Market Integration". Agricultural \& Applied Economics Association's 2013 AAEA \& CAES Joint Annual Meeting.ageconsearch.umn.edu accessed on March 12,2021

Bloom David E. (2011). "Population Dynamics in India and Implications for Economic Growth", program on global demography of aging (PGDA) Working Paper No. 65, Harvard School of Public Health, https://core.ac.uk/download/pdf/6494801.pdf accessed on March 16, 2021

Burchi Francesco and Muro De Pasquale (2012). "A Human Development and Capability Approach to Food Security: Conceptual Framework and Informational Basis" Working paper united nations development programme WP 2012-009: February 2012

https://www.undp.org/content/dam/rba/docs/Working\%20Papers/Capability\%20Approach\%20F ood\%20Security.pdf accessed on Feb11, 2020

Ministry of agriculture cooperation and farmers' welfare government of India (March 2020) "agriculture statistics at a glance 2019", Directorate of economics and statistics

https://eands.dacnet.nic.in/

Directorate of economics and statistics. (2018). "Pocket book of agriculture statistics 2017" (Page 14) Government of India, https://agricoop.nic.in/sites/default/files/pocketbook_0.pdf accessed on January 3, 2021

Department of food and public distribution (2020). "Procurement figures" Government of India, https://dfpd.gov.in/procurement-figures.htm accessed on February 6, 2021

India Economic Snapshot - OECD_accessed on March 23, 2021

Ministry of health \& family welfare, Government of India. (2019). "Population projections for India and states 2011 - 2036" report of the technical group on population projections, https://nhm.gov.in/New_Updates_2018/Report_Population_Projection_2019.pdf accessed on Feb 20, 2021

National food security portal, Department of food and public distribution, Government of India,https://nfsa.gov.in/public/nfsadashboard/PublicRCDashboard.aspx

NFSA government of India https://nfsa.gov.in 
International Journal of Social Science and Economic Research

ISSN: 2455-8834

Volume:06, Issue:07 "July 2021"

Pillay D P K and Kumar manoj P K, (Feb 2019), "Food security in India, evolution efforts and problems", Strategic analysis, volume 42, issue 6, Taylor and Francis online. Accessed on March 13, 2021

Press information bureau government of India, Pib.gov.in, accessed on February 12, 2021

'Probe misuse of food to anganwadis', February2011

https://www.deccanherald.com/content/138409/probe-misuse-food-anganwadis.html

Kakwania Nanak and H. Son Hyun. (2017), "Measuring food insecurity: Global estimates" www.un.org accessed on April 1, 2021

SainiShwetaandGulatiashok. (2016). "India's Food Security Policies in the Wake of Global Food Price Volatility".Food Price Volatility and Its Implications for Food Security and Policy pp. 331-352, link.springer.com accessed on March21, 2021

Singh anamika .(2019). “India's performance in Global Hunger Index \& its initiatives to address malnutrition" NitiAayog.

https://niti.gov.in/writereaddata/files/document_publication/Indias\%20performance\%20in\%20G1 obal\%20Hunger\%20Index.pdf accessed on January 11, 2021

United Nations, Department of economic and social affairs-sustainable development. https://sdgs.un.org/goals/goal2

World global hunger index (2020). https://www.globalhungerindex.org/ranking.html www.un.org/development/desa/disabilities/envision2030-goal2.html accessed on Dec 11,2020 